University of Nebraska - Lincoln

DigitalCommons@University of Nebraska - Lincoln

Pyrrolizidine Alkaloid- Containing Toxic Plants (Senecio, Crotalaria, Cynoglossum, Amsinckia, Heliotropium, and Echium spp.)

Bryan L. Stegelmeier

USDA-Agricultural Research Service, bryan.stegelmeier@ars.usda.gov

Follow this and additional works at: https://digitalcommons.unl.edu/usdaarsfacpub

Part of the Agricultural Science Commons

Stegelmeier, Bryan L., "Pyrrolizidine Alkaloid- Containing Toxic Plants (Senecio, Crotalaria, Cynoglossum, Amsinckia, Heliotropium, and Echium spp.)" (2011). Publications from USDA-ARS / UNL Faculty. 877. https://digitalcommons.unl.edu/usdaarsfacpub/877

This Article is brought to you for free and open access by the U.S. Department of Agriculture: Agricultural Research Service, Lincoln, Nebraska at DigitalCommons@University of Nebraska - Lincoln. It has been accepted for inclusion in Publications from USDA-ARS / UNL Faculty by an authorized administrator of DigitalCommons@University of Nebraska - Lincoln. 


\title{
Pyrrolizidine Alkaloid- Containing Toxic Plants (Senecio, Crotalaria, Cynoglossum, Amsinckia, Heliotropium, and Echium spp.)
}

\author{
Bryan L. Stegelmeier, DVM, PhD
}

\section{KEYWORDS}

- Pyrrolizidine $\bullet$ Alkaloid $\bullet$ Toxic plants $\bullet$ Senecio $\bullet$ Crotalaria

- Amsinckia

Many problematic pyrrolizidine alkaloid (PA)-containing plants are foreign invasive weeds that invade pastures, fields, and ranges, and contaminate feeds and food. Others are native plants that may increase or expand on field edges or in disturbed areas. Most are unpalatable, only becoming a problem for livestock when alternative forages are unavailable, or when they are included in hay and other harvested feeds. Human poisoning is most often a result of contaminated grain or flour, although several poisonings have resulted from the use of PA-containing herbal preparations. Major PA plants and their specific health-related characteristics are discussed individually.

\section{INDIVIDUAL PYRROLIZIDINE PLANTS \\ Senecio Species}

More than 3000 Senecio species are found throughout the world. Of these, reports document that approximately 30 have produced livestock and human poisoning such as "stomach staggers," "walking disease," "Pictou disease," "Winton disease," "Molteno," "dunziekte," and "sirasyke."1,2 Although many other species contain PAs and have toxic potential, their growth patterns and lack of palatability makes

\footnotetext{
The author has nothing to disclose.

USDA-Agricultural Research Service, Poisonous Plant Research Laboratory, 1150 East, 1400 North, Logan, UT 84341, USA

E-mail address: Bryan.Stegelmeier@ARS.USDA.gov
} 
poisoning infrequent. The "more toxic" species are expansive and invasive, allowing them to contaminate feeds and food and dominate plant communities. Senecio species that commonly poison livestock in North America include $S$ jacobaea, riddellii, douglasii var. longilobus, and vulgaris. Other "less toxic" Senecio species have been suspected of poisoning, suggesting that their identity should be confirmed and their toxicity evaluated chemically (Fig. 1).

$S$ jacobaea or tansy ragwort is an invasive noxious western European weed that was inadvertently introduced into Eastern Europe, South Africa, Australia, New Zealand, and North America. In the Pacific Northwest, tansy ragwort often invades pastures and fields. Although it is not very palatable and generally not eaten by livestock, poisoning occurs when plants or seeds contaminate feeds, when grazing animals cannot easily differentiate the early rosette from adjacent forage, or when no other forages are available. $S$ jacobaea contains six toxic PAs. The chronic lethal dose in cattle is approximately $2.5 \mathrm{mg}$ total PA per kilogram of body weight (bw) for 18 days, suggesting that a cow would need to eat approximately $1.7 \mathrm{~kg}$ of fresh plant per day for several weeks to obtain a lethal dose. Higher doses cause acute hepatocellular necrosis and liver failure, but these poisonings are rare because these doses are unpalatable.

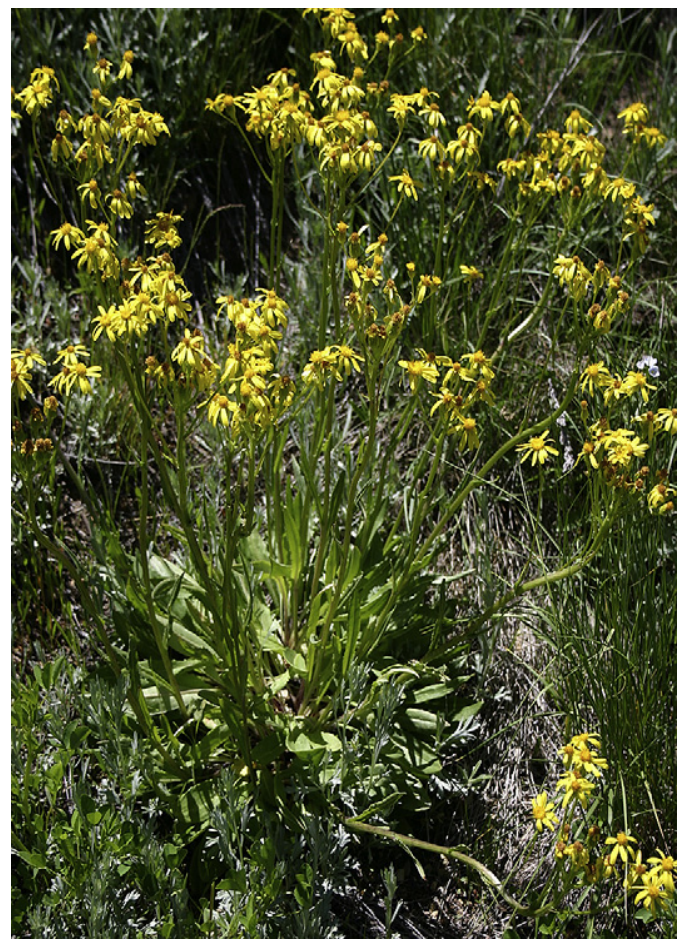

Fig. 1. Senecio hydrophiloides (stout meadow groundsel) in the flower. Notice the composite flower typical of most Senecio plants. This species is a less common pyrrolizidine alkaloid-containing plant that usually is a minor member of plant communities in the western states. However, it is toxic and under some conditions may proliferate or animals may be forced to eat it and poisoning is possible. Similar minor Senecio species can be found in most plant communities. 
$S$ riddellii or Riddell groundsel is found in Nebraska, New Mexico, Texas, Colorado, and Wyoming. S riddellii differs from other Senecio species in that it contains a single major alkaloid, riddelliine. Alkaloid concentrations vary, with PA concentrations in plants collected from the same site ranging from $0.2 \%$ to $18.0 \%$ (dry weight). S riddellii is toxic to cattle at PA doses of $15 \mathrm{mg} / \mathrm{kg}$ bw for 20 days or approximately $176 \mathrm{~g}$ of fresh $S$ riddellii per day. Although riddelliine is less toxic than PAs from other Senecio species, the plant can contain more toxin, making the whole plant highly toxic. Riddelliine has also been shown to be carcinogenic to rodents.

$S$ douglasii var. longilobus, or threadleaf or woolly groundsel (Fig. 2), is a perennial branched shrub that grows on abused or degraded arid rangelands of the southwestern states. It contains four alkaloids with concentrations varying from $0.63 \%$ to $2.02 \%$ of the plant dry weight, suggesting that approximately $750 \mathrm{~g}$ of green plant for 15 days would be lethal for cattle.

$S$ vulgaris or common groundsel is an erect, annual or biennial plant that has been historically used for medicinal purposes. However, it can contaminate feeds and several reports exist of poisoning in horses. Plant PA concentrations vary from $0.63 \%$ to $2.02 \%$ of the plant dry weight, suggesting that approximately $250 \mathrm{~g}$ of green plant per day for 15 days will poison cattle.

\section{Crotalaria Species}

Most species of Crotalaria that contain PAs were introduced into North America as soil-enriching cover crops. Some escaped cultivation and often spread along fencerows and ditch banks where they may spread and contaminate pastures and fields. Most have long, kidney-shaped seeds that rattle in mature dry pods, resulting in the common name "rattle pod." The seeds can be harvested with grains to contaminate feeds and foods. sagittalis poisoning, originally called Missouri Bottom disease, produces liver disease, and causes horses to appear slow, emaciated, weak, and stuporous. Horses that are highly susceptible are most often poisoned when grazing C sagittalis-infested stubble fields. Crotalaria seeds contaminating grain have poisoned both livestock and poultry.

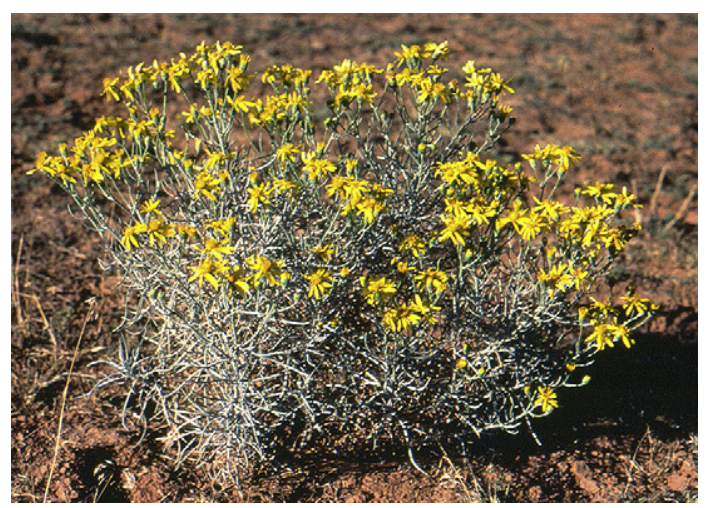

Fig. 2. Senecio douglasii var. longilobus (wooly groundsel) in the flower. Wooly groundsel is a woody bush that grows up to $1.5 \mathrm{~m}$ tall in the southwestern United States. Poisoning occurs when animals are forced to eat it or it is included in stored feeds. 


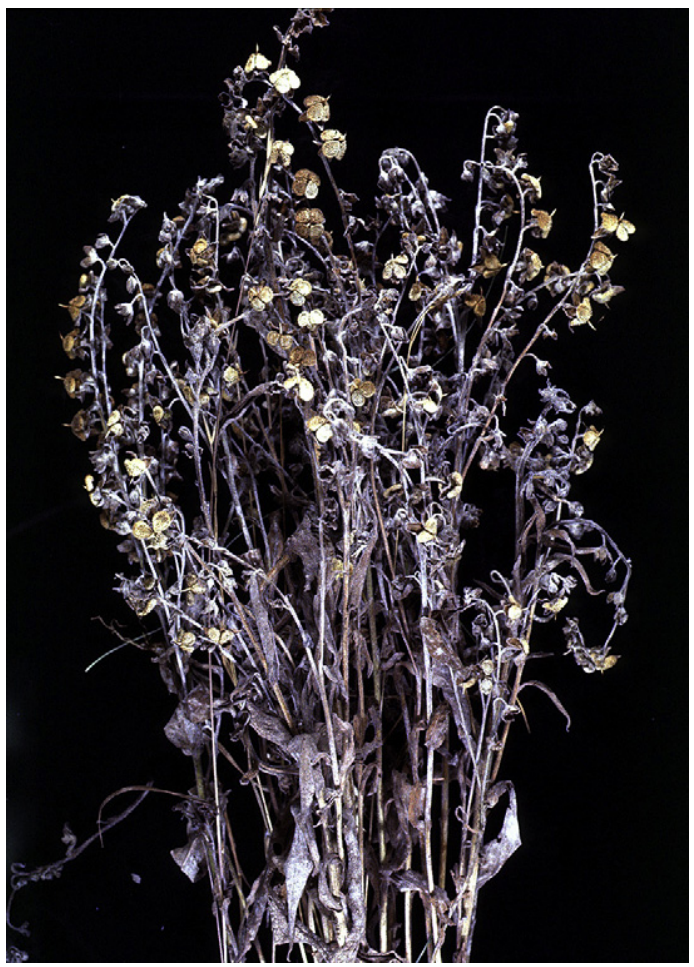

Fig. 3. Cynoglossum officinale (houndstongue) dry senescent plant. Houndstongue is a biennial noxious weed that has invaded fields, pastures, and many ranges. It grows approximately $0.5 \mathrm{~m}$ tall and produces small burrs that are easily transported on fur, tack, and clothing. As a noxious weed is has become a large concern because it has infested many national forests and public lands.

\section{Cynoglossum Officinale}

Cynoglossum officinale, or houndstongue, is a biennial European plant that invades pastures, rangelands, and fields (Fig. 3). It is generally unpalatable to livestock, and most poisoning occurs when animals are fed contaminated feed. Hound's tongue contains four PAs, with heliosupine the most abundant and toxic. PA concentrations range from $0.5 \%$ to $2.2 \%$, suggesting that $680 \mathrm{~g}$ of green plant per day for 14 days would be lethal for cattle.

\section{Heliotropium and Echium}

Species of both are intermittently reported to poison Australian livestock. Echium plantagineum, commonly called Patterson's curse or Salvation Jane, is a noxious weed that can replace alternative forages and poison livestock. Sheep are relatively resistant, but horses and other livestock are susceptible. Heliotropium europaeum is a Mediterranean annual that can invade fields and contaminate feeds and food. In Australia it has been reported to poison pigs, cattle, and sheep. However, although it grows in the southern United States, it is rarely reported to cause poisoning. Recent studies documenting PA contamination to honey and wildlife intoxications have renewed interest in both Echium and Heliotropium toxicity. 


\section{Other PA-Containing Boraginaceae Plants}

Amsinckia intermedia, commonly called tarweed or fiddleneck, is an annual weed that grows in waste areas and fields. Amsinckia is not highly toxic, but it has been reported to cause walking disease in horses and hard liver disease in cattle and swine.

Symphytum officinale, or comfrey, has been used as both forage and a medicinal herb. It contains several PAs and has been shown to cause disease in both experimental animals and humans. Low doses of comfrey have been shown to produce hepatic neoplasms in rodents. This finding has led to increased restriction of its sale, and most herbal companies no longer market comfrey-containing products. However, it continues to be used in herbal preparations on an individual basis.

Several other plants, including members of the Borago and Trichodesma genera, also contain small amounts of PAs (Table 1). Although some are used as medicinal plants and herbs, little information exists on the toxic effects of low-dose PA exposure associated with these plants.

\section{TOXICOKINETICS AND MECHANISM OF ACTION}

Plant PAs are composed of free base and $N$-oxides and, because both are toxic, should be analyzed and included when determining plant toxicity. PAs are not directly toxic. To become toxic they must be bioactivated by mixing function oxidases to toxic dehydropyrrolizidine alkaloids (pyrroles). Most activation occurs in the liver, which most often results in hepatic damage. Nontoxic metabolites are also produced and quickly excreted. The toxic species damage the adjacent tissues because they are potent electrophiles, and they bind to and cross-link DNA, proteins, amino acids, and glutathione. Depending on the extent and location of the damage, the results are both cytotoxic and antimitotic. ${ }^{1}$ Some pyrrole-tissue adducts may persist for months or years and may even be recycled, producing additional damage.

\section{TOXICITY AND RISK FACTORS}

Despite similar structures, acute PA toxicity is highly variable and pyrrole-specific. For example, the reactive metabolites of seneciphylline and retrorsine are primarily hepatotoxic. Less-reactive PAs, such as trichodesmine and monocrotaline, produce more stable pyrrole intermediates, resulting in fewer hepatic changes with extensive extrahepatic lesions. Susceptibility to poisoning is influenced by species, age, sex, and other temporary factors, such as biochemical, physiologic, and nutritional status.

Different animal species have vastly different susceptibilities to PAs. For example, the toxic doses of some plants are estimated to be 20 times higher for sheep than those that kill cattle. Consequently, experts have suggested that sheep and goats be used to graze pastures that are dangerous to horses and cattle. The relative species susceptibilities to PA poisoning are: pigs $=1$; chickens $=5$; cattle and horses $=14$; rats $=50$; mice $=150$; and sheep and goats $=200$. $^{3}$ Some have suggested that these differences are because of rumen embolism, but it seems like it is a combination of metabolism and species-specific hepatic metabolism.

Age, gender, and nutritional status are also important factors. Young animals are generally more susceptible, and neonatal and nursing animals and humans may develop fatal hepatic disease while their lactating mothers were unaffected. Male rats are more susceptible to poisoning than females. Animals with marginal nutrition or stress with excessive hepatic copper are also more susceptible to PA poisoning. These differences have also been linked to metabolic rates, and toxicity is thought 


\begin{tabular}{|c|c|}
\hline \multicolumn{2}{|l|}{ Compositae } \\
\hline Senecio abyssinicus & Rats \\
\hline S alpinus & Cattle \\
\hline$\underline{S \text { bipinnatisectus }}$ & Calves \\
\hline S brasiliensis & Cattle \\
\hline S burchelli & Cattle \\
\hline S cisplatinus & Livestock \\
\hline S desfontainei & Poultry \\
\hline S douglasii var. longilobus & Cattle, rodents \\
\hline S erraticus & Cattle, horses, sheep \\
\hline Sglabellus & Livestock, rats \\
\hline S heterotrichius & Cattle \\
\hline S integerrimus & Livestock \\
\hline$\underline{\text { S jacobaea }}$ & Livestock, rodents, poultry \\
\hline S latifolius & Cattle \\
\hline Slobatus & Cattle \\
\hline Slautus & Cattle \\
\hline S leptolobus & Cattle \\
\hline S madagascariensis & Horses \\
\hline S montevidensis & Cattle \\
\hline S oxyphyllus & Cattle \\
\hline Spampeanus & Cattle \\
\hline S plattensis & Horses \\
\hline$\underline{\text { Squadridentatus }}$ & Cattle \\
\hline S raphanifolius & Yaks \\
\hline$\underline{S \text { retrorsus }}$ & Wildlife \\
\hline$\underline{\text { S riddellii }}$ & Livestock \\
\hline$\underline{\text { S sanguisorbae }}$ & Sheep \\
\hline$\underline{\text { S selloi }}$ & Cattle \\
\hline S spartioides & Livestock \\
\hline S spathulatus & Cattle \\
\hline S subalpinus & Cattle \\
\hline$\underline{\text { Stweediei }}$ & Cattle \\
\hline S vernalis & Goats \\
\hline$\underline{S \text { vulgaris }}$ & Horses, rodents \\
\hline \multicolumn{2}{|l|}{ Leguminosae } \\
\hline Crotalaria anagyroides & Cattle \\
\hline C assamica & Mice \\
\hline C equorum & Horses \\
\hline C goreensis & Chickens \\
\hline C incana & Man \\
\hline C juncea & Cattle, horses, pigs \\
\hline & (continued on next \\
\hline
\end{tabular}




\begin{tabular}{|ll}
\hline $\begin{array}{l}\text { Table } 1 \\
\text { (continued) }\end{array}$ \\
C laburnoides & Man \\
\hline C mucronata & Sheep, cattle \\
\hline C nana & Man, rats \\
\hline C retusa & Poultry, pigs \\
\hline C sagittalis & Horses \\
\hline C saltiana & Goats, mice, calves \\
\hline C spectabilis & Livestock, rodents, poultry \\
\hline C verrucosa & Man \\
\hline Boraginaceae & \\
\hline Amsinckia intermedia & Livestock, rodents \\
\hline Cynoglossum officinale & Cattle, horses \\
\hline Echium plantagineum & Livestock, rodents \\
\hline Heliotropium amplexicaule & Cattle \\
\hline$H$ dasycarpum & Sheep \\
\hline$H$ europaeum & Livestock, poultry, rodents \\
\hline$H$ lasiocarpum & Man \\
\hline$H$ ovalifolium & Sheep, goats \\
\hline$H$ scottae & Mice \\
\hline$H$ supinum & Rats \\
\hline Symphytum officinale & Man, rodents \\
\hline S peregrinum & Poultry \\
\hline Trichodesma ehrenbergii & Poultry \\
\hline
\end{tabular}

Data from Mattocks AR. Chemistry and toxicology of pyrrolizidine alkaloids. Orlando (FL): Academic Press; 1986. p. 1-13, 130-57, 158-90; and Stegelmeier BL, Edgar JA, Colegate SM, et al. Pyrrolizidine alkaloid plants, metabolism and toxicity. J Nat Toxins 1999;8(1):95-116.

to be linked to both the ability of the liver to synthesize and metabolize pyrroles and the hepatic ability to repair pyrrole-induced damage.

Plant and plant/animal interactions also contribute to toxicity. Palatability, the amount and rate that animals eat, varies with season, location, weather, and the availability of other forages. Usually plants are most toxic in the early bud stage when beginning to flower. However, huge variations exist in PA concentrations from year to year and from site to site, making it difficult to predict when a particular group of plants will contain toxic PA concentrations. ${ }^{1}$

\section{Clinical, Biochemical, and Histologic Lesions}

Cellular indications of PA intoxication are first seen as dose-dependent hepatocyte swelling. With continuing damage, cellular degeneration continues, with ultimate loss of cellular homeostasis and necrosis or cell death. Histologically, this is seen as acute hepatocellular necrosis or more chronic hepatic fibrosis and biliary proliferation. High PA doses ingested quickly cause acute intoxication, with panlobular hepatocellular necrosis accompanied by hemorrhage and minimal inflammation (Fig. 4). These animals show signs of acute liver failure, including anorexia, depression, icterus, visceral edema, and ascites. Serum biochemical changes include massive elevations in aspartate amino transferase (AST), sorbitol dehydrogenase (SDH), alkaline phosphatase (ALK), and gamma glutamyl transpeptidase (GGT) activities, with increased 


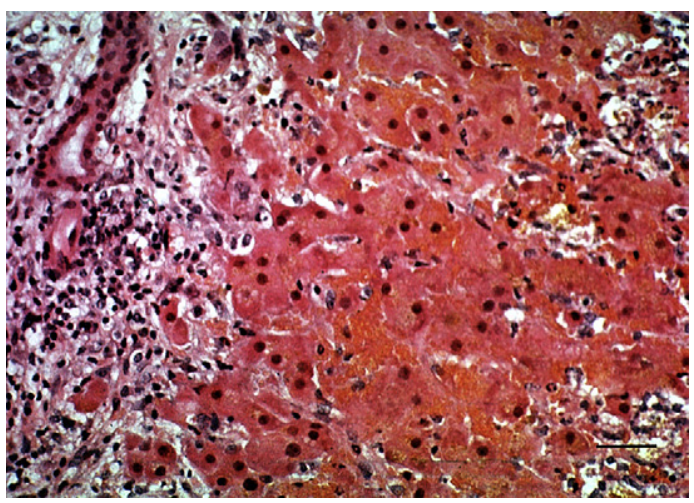

Fig. 4. Photomicrograph of the liver of a horse poisoned with $15 \mathrm{mg}$ of Cynoglossum officinale pyrrolizidine alkaloids for 14 days. Notice the massive hepatocellular necrosis and hemorrhage (Hematoxylin-eosin, original magnification $\times 30 \mu \mathrm{m}$ ).

amounts of bilirubin and bile acids. These conditions must be differentiated from other toxic, viral, and immunologic diseases that cause extensive hepatic necrosis. Fortunately, these animals have high concentrations of tissue-bound pyrroles that can be extracted and detected chemically.

Chronic poisoning is caused by lower PA doses of longer duration. Initially these may not be apparent clinically, because animals develop transient elevations in serum enzymes (AST, SDH, ALK, and GGT). They may have mild elevations in serum bilirubin and bile acids. Hepatic biopsies often have focal hepatocyte necrosis (piecemeal necrosis), minimal peribiliary fibrosis, and mild bile duct proliferation. With time, damaged hepatocytes often develop into large megalocytes (Fig. 5). Animals may show no clinical signs, and serum biochemistries may be normal for several months or even years after PA ingestion. However, hepatocellular damage may continue, resulting in continued hepatocyte necrosis with subsequent inflammation, fibrosis, and ultimately cirrhosis. With loss of hepatic function, poisoned animals often do poorly. When these hepatic cripples are subjected to physiologic stresses, such as

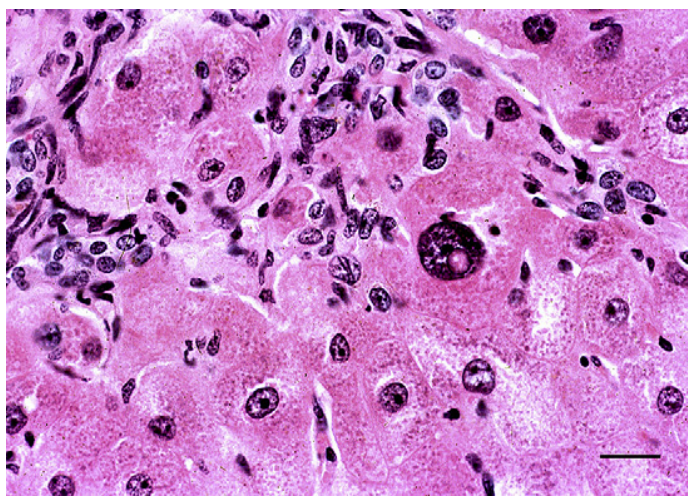

Fig. 5. Photomicrograph of liver from a horse dosed with $5 \mathrm{mg}$ of Cynoglossum officinale pyrrolizidine alkaloids per kilogram of body weight for 14 days. Note the megalocytes (enlarged hepatocyte) with large nucleus and biliary proliferation (Hematoxylin-eosin, original magnification $\times 100 \mu \mathrm{m}$ ). 
pregnancy or lactation, they develop clinical liver failure with photosensitivity, icterus, and increased susceptibility to hepatic lipidosis or ketosis. Because this can develop months after PA exposure, the PA-containing plant or feed contaminant is difficult to identify. Initial kinetic studies found that these animals had low concentrations of tissue-bound pyrroles that may not be detected. ${ }^{4}$

\section{DIAGNOSTIC TESTING}

Because clinical signs of poisoning can be delayed, exposure to PA-containing plants may be difficult to document. Many diagnoses are made using characteristic histologic changes alone (hepatic necrosis, fibrosis, biliary proliferation, and megalocytosis) (Fig. 6). Unfortunately, these are nonspecific changes and a definitive diagnosis is difficult. The ubiquitous nature of PA-containing plants suggests that PA intoxication is underdiagnosed. Although chemical methods using spectrophotometry and gas chromatography/mass spectrometry can identify tissue-bound pyrroles (PA-metabolites), these assays lack sensitivity and are not quantitative. Improved sensitive diagnostics, including enzyme-linked immunosorbent assay (ELISA)-based immunodiagnostics, are needed to definitively identify PA adducts and provide more information on pyrrole kinetics, possible pyrrole recycling, or the cumulative effects of poisoning.

\section{TREATMENT AND PROGNOSIS}

The progressive nature of chronic PA intoxication suggests that low chronic PA exposure has cumulative effects. Little is known about what doses or durations are damaging, or the effect of subclinical intoxication on growth or productivity. Although various treatments and diet supplements have been suggested, none have been effective in livestock. Poisoned animals that show clinical signs rarely recover.

\section{PREVENTION AND CONTROL}

Prevention is the best control measure. Because most poisonings are attributed to contamination of forages or feed, careful inspection of feed is recommended.

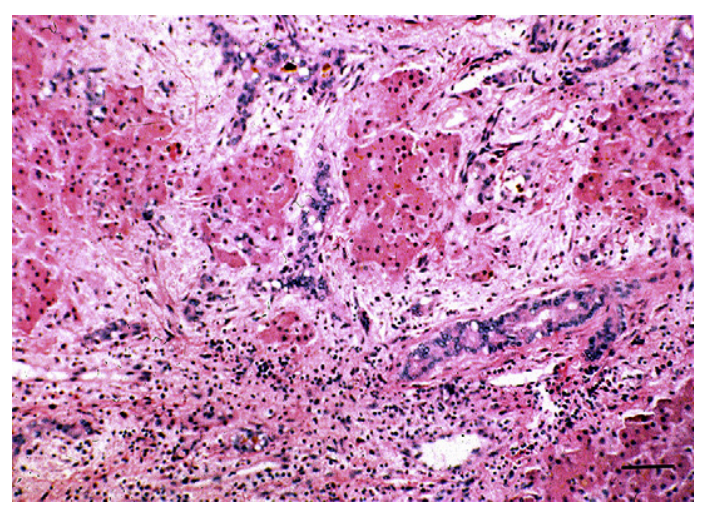

Fig. 6. Photomicrograph of liver from a cow dosed with $15 \mathrm{mg}$ of Senecio longilobus pyrrolizidine alkaloids per kilogram of body weight for 14 days. Notice the extensive fibrosis with adjacent hepatocellular degeneration and necrosis. Extensive proliferation of biliary epithelium is also present (Hematoxylin-eosin, original magnification $\times 50 \mu \mathrm{m}$ ). 
Contaminated feeds should be discarded or fed to less-susceptible species. Inspection of fields before harvest provides the best chance of detecting PA-containing plants. Although most PA-containing plants are not highly palatable, eliminating them from pastures and ranges is also recommended. Species-specific herbicide regimens have been developed for most plants and are widely available through county weed and extension services.

\section{REFERENCES}

1. Mattocks AR. Chemistry and toxicology of pyrrolizidine alkaloids. Orlando (FL): Academic Press; 1986. p. 1-13, 130-57, 158-90.

2. Johnson AE, Molyneux RJ, Ralphs MH. Senecio: a dangerous plant for man and beast. Rangelands 1989;11:261-4.

3. Hooper PT. Pyrrolizidine alkaloid poisoning- Pathology with particular reference to differences in animal and plant species. In: Keeler RF, editor. Effects of poisonous plants on livestock. New York: Academic Press; 1978. p. 161-76.

4. Stegelmeier BL, Edgar JA, Colegate SM, et al. Pyrrolizidine alkaloid plants, metabolism and toxicity. J Nat Toxins 1999;8(1):95-116. 